\title{
A humánerőforrás-gazdálkodás kérdései a magyar agráriumban
}

\author{
Horváthné Petrás Viktória, ${ }^{1}$ Bertalan Péter $^{2}$
}

\begin{abstract}
Human Resource Management Issues in the Hungarian Agrarian Sector. The aim of Human Resources Management (HR) is to efficiently handle the human resources and thereby to contribute to organizational efficiency, that is, the maintaining and increasing of the performance of an organization. HR not only provides the necessary conditions but also encourages employers to implement improvements, in accordance with their own individual, group and organizational interests, which serve the company' goals. The economic and social changes taking place in our country have become significant factors of the efficient production in agriculture. In the current situation of the agricultural sector, the efficient use of manpower can be one of the breakout points in the future. This article provides an overview of the present situation of human resources management as well as the roles and functions it fulfils in the Hungarian agriculture.
\end{abstract}

Keywords HR in Agriculture, Hungarian agriculture, performance appraisal

\section{Bevezetés}

Az emberi erőforrás menedzsment célja és értelme az emberi erőforrás hatékony menedzselése és a szervezeti hatékonyság, a szervezet fennmaradásának és növelésének biztosítása, a szervezeti teljesítmény növelésének elősegítése. Az emberi erőforrás menedzsment, vagy népszerü, rövidebb kifejezéssel élve a HR, nagy utat járt be az utóbbi évtizedekben kiszélesedtek funkciói, egyre fontosabb szerepet töltenek be a stratégiai döntéshozatalban is (Petró et al. 2013). A legfontosabb változást a technikai tényezők váltásával egyidejüleg az emberi erőforrások középpontba állítása jelentette, mivel a kialakult gazdasági helyzetben releváns versenyelőnyt csak a rendelkezésre álló munkaerő-állomány minőségének javításával, képességeinek minél teljesebb kihasználásával,

${ }^{1}$ Kaposvári Egyetem Gazdálkodás- és Szervezéstudományok Doktori Iskola

E-mail: horvathne.petrasviktoria@gmail.com

${ }^{2}$ Kaposvári Egyetem Gazdálkodás- és Szervezéstudományok Doktori Iskola

E-mail: drbertalanp@gmail.hu 
illetve tevékenységük szervezésének optimalizálásával lehet elérni. Az emberi tényezők, úgymint tudás, képesség, magatartás és a hatékony személyzetmenedzselés váltak napjainkra a versenyképesség új forrásaivá (Fekete, 2006).

Egy szervezet sikere több termelési tényezőn múlik, versenyképességének megőrzésében és a vállalat fejlődésében legjelentősebb erőforrásként mégis az emberi tőke jelenik meg, hiszen rajtuk múlik a többi erőforrás optimális kihasználása és összehangolása is. Ezt a fajta szemléletet már egyre több helyen ismerik fel és alakítják ki ennek megfelelően szervezeti és humán erőforrás stratégiájukat. Az emberi erőforrás, vagy emberi tőke a vállalat számára különleges erőforrásként jelenik meg (Lepp, 2008).

\section{Az emberi erőforrás menedzsment kialakulása, története}

Az emberi erőforrás menedzsment kialakulása egészen az 1800-as évekre vezethető vissza, amikor is Angliában kialakult a welfare personnel (WP) szociálpolitikai személyzet fogalma, amely feladata a szociális programok kidolgozása és megvalósítása volt. További fejlődési szakaszit nagymértékben meghatározták a történelmi események sorozatai, amely során ismételten Anglia jelentős szerepet töltött be. Az ipari forradalom hatására kialakult szabad versenyes kapitalizmussal egy időben megjelentek a társadalmi reformerek, akik a munkáltatók magatartását bírálva, a munkavállalók érdekeit próbálták meg képviselni, mely fellépés eredményeképpen a munkaadók személyzetis ügyekkel, feladatokkal foglalkozó embereket kezdtek el alkalmazni. E téren Robert Owen munkásságának kiemelkedő szerepet tulajdonítanak.

A XIX. sz. végén egyes vállalatok jótékonysági intézkedéseinek köszönhetően jelentős változások következtek be a munkaadók munkavállalóikhoz füződő viszonyulásában. Megjelent a munkanélküli segély és a lakástámogatás, mint központi gondolat kialakult a szociális gondoskodás intézménye is, amely a mai napig részét képezi az emberi erőforrás menedzsmentnek.

Az 1920-as évekre a megemelkedett munkavállalók számának következményeként, kialakult a személyügyi menedzser, aki a bürokratikus rendszerben, a szervezet müködését elősegítve az alkalmazottakkal kapcsolatos szociális feladatokat látott el. A feladatkör elvégzésében a „személyzetis” gondolkodását a taylori és a fayoli tanok eszméi határozták meg, melynek legfőbb képviselője Elton Mayo volt.

A második világháború következményeként,- magas foglalkoztatási ráta mellett is tapasztalható munkaerőhiány- megerősödtek a dolgozók érdekeiért harcoló szakszervezetek.

Későbbiekben a kiélesedett gazdasági verseny hatására, a termelékenységi mutatók fokozása érdekében már a kormányzatok is támogatták a szakmailag jól felkészült személyzetis szakemberek alkalmazását.

A történelmi hatások és eme tudományterület fejlődésének eredményeképpen az emberi erőforrás menedzsment a dolgozó egyéneket emberi erőforrásnak tekinti, és ennek megfelelően kezeli. Kialakul az ember, mint befektetett tőke gondolat, jellemzővé válik a munkaerö-tervezés és a szervezet humán stratégiájának kidolgozása.

A humánerőforrás gazdálkodás Európában végbemenő kialakulásához, fejlődéseséhez nagymértékben hasonlít az a folyamat, amit az Amerikai Egyesült Államoknál tapasztalhatunk, bár a gazdasági fejlődés mértékének különbözősége, másodsorban az állami beavatkozásoknak köszönhetően jelentős eltérések figyelhetők meg (Fejes, 2013 29-38). 


\section{Magyarországi történeti jellemzők}

Hazánkban három szakaszra (II. világháborúig terjedő időszakra, a szocializmus időszakára és a napjainkig tartó társadalmi időszakra) osztható a személyügyi munka, az emberi erőforrás, az emberi erőforrás menedzsment története. A történelmi események hazánkban is jelentős hatással voltak e fejlődési szakaszok kialakulására éppúgy, mint Európa többi országában.

A személyzeti politika hazánkban több mint 100 éves múltra tekint vissza. Már a második világháborút megelőzően a versenyszférában találunk a nyugati fejlődési fázisokhoz hasonló nyomokat, melyek 1945 után teljesen elkülönültek köszönhetően a szocialista ideológia hatásainak. Ebben az időszakban a személyzeti munka kizárólag politikai és adminisztratív tevékenységek elvégzésére volt hivatott. A személyzeti munka jelentésének értelmezésében csak az 1980-as évek politikai változásai vetett véget. A gazdasági körülmények megváltozásának eredménye képpen bontakozott ki az a nézet, amely a szervezeti viszonyok és a személyzeti munka egyidejü és együttes reformjának fontosságát is hangsúlyozta.

A humánerőforrás gazdálkodás hazai fejlődési szakaszait bezáró utolsó fejezet az 1990-es évekhez köthető, amikor is kialakul az a szemlélet - az európai tendenciához hasonlóan-, melyben az ember, mint tőke avagy, mint termelési tényező fogalmazódik meg (Fejes, 2013).

\section{A humánerőforrás gazdálkodás fogalma, jelentősége}

A humánerőforrás a szervezetek müködtetése szempontjából megfogalmazott, széles körben használt kifejezés a szervezet munkatársai összességének megnevezésére.

Definiálni sokan, és sokféleképpen próbálták, íme, egypár példa erre:

- Pfau (1998, 133) szerint ,az emberi erőforrás fogalmának használata, a korábbi munkaerő fogalmának használata helyett helytállóbb, hiszen a munkavállaló a termelés egyik erőforrása, aki rendelkezik az erőforrásokra jellemző valamennyi tulajdonsággal, mivel a termelésben új érték előállítására képes. Ugyanakkor megállapítható, hogy jelenleg a gyakorlatban mindkét fogalmat gyakran felváltva használják."

- Chikán (1999, 254-255) megfogalmazásában ,az emberi erőforrás a vállalatnál alkalmazott munkavállalóknak a munkavégzéshez szükséges képességeik, szakismeretük és a munkamegosztásban elfoglalt helyük szerint strukturált összessége. A munkaerővel azonos értelemben használjuk.”

- McKenna és Beech (1998, 13-19) megfogalmazása szerint ,az emberi erőforrás menedzsment (HRM) a személyzeti munka viszonylag új típusú megközelítésének tekinthető, amely az embert tartja a legfontosabb erőforrásnak. Arra az elképzelésre épül, hogy fontos az alkalmazottakkal való megfelelö kommunikáció, fontos bevonni őket a folyamatban lévő dolgokba, illetve fontos a szervezet iránti elkötelezettségük és az azzal való azonosulásuk elősegítése. A 
fentiek mellett nagy hangsúlyt kap a munkaerő megszervezésének, irányításának és motivációjának stratégiai megközelítése". A hazai szakirodalom is elfogadta a fenti gondolatokat (Lévai 1992, 17).

- Dobák (1999, 140-144) szerint az emberi erőforrás menedzsment (EEM) a szervezeti célok kialakításának és megvalósításának elősegítésére, valamint a szervezet megfelelő mennyiségű és minőségű munkaerővel való folyamatos ellátására irányul. A végső cél a szervezeti hatékonyság biztosítása, ami a társaságok hosszú távon való fennmaradását és fejlődését, növekedését eredményezi.

- Fekete Rita (2006)-ban íródott doktori értekezésében a következők olvashatóak:" Az emberierőforrás-menedzsment célja a szervezeti hatékonyság biztosítása a szervezeti célok megvalósításának segítésével, jól képzett, megfelelően motivált alkalmazottak biztosításával. Az emberierőforrás-menedzsment tevékenységének célja a szervezeti teljesítmény és a stratégiai célok elérésének biztosítása a költséghatékonyság, a növekedés, a túlélés és a szociális felelősségtudat jegyében."

- Bittner (2011) álláspontja, hogy a HR alapvető feladata, hogy az üzleti stratégiával egy időben elkészített HR stratégia alapján a pillanatnyi létszámadottságait figyelembe véve elkészítse a munkaerőtervet, és ennek alapján kövesse a változásokat, azaz gazdálkodjon a legértékesebb erőforrással az emberi erőforrással.

Emberi erőforrás menedzsment fogalma alatt mindazon tevékenységeket és vezetési módszereket értjük, amelyek egy adott szervezeten belül a munkaerő kiválasztásától, a munkaerő fejlesztésén keresztül a teljesítmény méréséig és a karrier menedzsmentig foglalkozik az emberi erőforrás müködésével és annak ésszerü, hatékony felhasználásával annak érdekében, hogy az egyéni- és szervezeti célok megvalósuljanak (Piros, 2002).

A múlt század 30-as, 40-es éveiben kezdett egyre nagyobb hangsúllyal elötérbe kerülni a vállalati gyakorlatban az ,emberi viszonyok tana” (Human Relations). Az új elvek arra alapozódtak, hogy a humán munkaeröre nagyobb hangsúlyt kell helyezni, és nem lehet azt a szociálpszichológiai tényezők megkerülésével vizsgálni (Hajós, 2007 p:7).

A szervezeti viselkedés vizsgálatának az a célja, hogy segítse a vezetőt a helyzetelemzésben, segítse felismerni a befolyásoló tényezőket, amelyek akár az emberre, akár a szervezetre hatással bírnak. A szervezeti viselkedés, mint tudomány megjelenésével a magatartástudománynak is meghatározó szerep jutott.

A HR alkalmazása nemcsak biztosítja a szükséges feltételeket, hanem arra ösztönzi a munkavállalókat, hogy saját egyéni és csoportos, valamint szervezeti érdekeik alapján további fejlesztéseket vigyenek véghez, ami a vállalati célok teljesítését is szolgálja. Azaz a gazdasági és szociális érdekek olyan összhangját sikerüljön kialakítani, amelyek hosszabb távon biztosítják egy emberek által fenntartott értékteremtő célzatú közösség társadalmi és gazdasági hasznosságát.

Az emberi tényező felértékelődött a stratégiai kezdeményezésekben, a versenyelőny megszerzésében és megtartásában. A tudás, a tapasztalat, a szakismeret a tőke egyik formája, a szervezeti vagyon része, szervezeti stratégiai erőforrás. Fejlesztése, müködtetése költséges, és jelentős befektetéseket igényel mind a személy, mind a szervezet részéröl. Az Európai Unióban az igazán fontos értékeink és specialitásaink között mindenekelőtt az emberi erőforrás minősége az első. Egyfelől elengedhetetlen, hogy a 
gazdasági növekedés növelje a munkaerő iránti keresletet, új munkahelyeket hozzon létre, ezáltal bővítve a foglalkoztatást, másfelöl a gazdaság tartós növekedésének feltétele, hogy többen dolgozzanak, és az emberi erőforrásainkban rejlő tartalékokra építve javuljon az ország versenyképessége.

Hazánkban meghatározó társadalmi és gazdasági átalakulás zajlott le. A változások a mezőgazdaságot is alapjaiban érintették. A termelőszövetkezetek, az állami gazdaságok, valamint a mezőgazdasági feldolgozóipar jelentős része átalakult a privatizáció és a kárpótlás során. Az állami és a szövetkezeti tulajdon mellett megjelentek és elterjedtek a különféle magántulajdoni formák és vállalkozási társulások. Korábban egy nagyvállalatként müködő, jól menedzselt egység a változásokat követően sok, másként menedzselhető kis egységekre szakadt. Az agrárágazat jelenlegi helyzetében az emberi erőforrás hatékony felhasználása egyik kitörési pont lehet a jövőben. Az emberi erőforrás menedzselés nemcsak egy vezetési funkció, hanem a vállalatok, vállalkozások versenyképességének legalapvetőbb eleme. Az elkövetkező időszak lehetőségeinek kihasználása, a mezőgazdasági társas vállalkozások talpon maradása, szervezeti hatékonyságuk növelése elsősorban azon a humán tőke bázison múlik, amely képes arra a szemlélet- és magatartásváltásra, ami a piaci mechanizmusok meghonosodása, gyakorlatba való integrációja szempontjából elsődleges jelentőséggel bír. A vállalkozásokat irányító elsőszámú vezetők kulcsszerepet játszanak, hiszen az ő szemléletmódjuk határozza meg elsősorban a modern irányítási technikák, emberi erőforrás menedzsment ismeretek gyakorlatban való alkalmazását (Hajós, 2007.).

\section{A HR és mezőgazdaság kapcsolata}

Az emberi erőforrás gazdálkodás mezőgazdasági sajátosságainak elemzését mindenekelőtt az ágazatban alkalmazott munkaerő jellegzetességeinek értékelésével kell kezdeni, mivel a mezőgazdasági munkafolyamatok sajátos munkakörülményeket jelentenek. A növénytermesztési feladatokat szabadföldi körülmények között kell elvégezni, ahol az időjárás hatásai - eső, sár, hideg, hőség, szárazság, por stb. - technikai eszközökkel ugyan csökkenthetők, de nem szüntethetőek meg. Hasonló a helyzet az állattenyésztési munkafolyamatokkal, ahol a biológiai folyamatok következményeként az állattartás és tenyésztés még sajátosabb munkafeltételek között folyik (Széles 2001). A takarmányozás, állatgondozás, állati terméknyerés, a trágyaeltávolítás, az állattartó épületek és telepek munkakörülményeit az alkalmazott munkaerőnek el kell fogadnia. Ráadásul a mezőgazdasági munkafolyamatok jelentős része ugyan gépesíthető, de nem automatizálható. Ez azt jelenti, hogy még a gépesített munkafolyamatok esetében a munkamüveletek egy részét manuálisan kell elvégezni (fejés, nyírás), és az ember közvetlen közremüködése a technikai eszközök üzemeltetésében is nélkülözhetetlen. A munkafolyamatok végrehajtásában a technikai, technológiai tényezők mellett folyamatosan figyelemmel kell lenni a biológiai folyamatokra, az időjárási és ökológiai feltételek változására. Ezekhez a feltételekhez, változásokhoz a munkavégzés során folyamatosan alkalmazkodni kell (Buzás, 2001). Ez szakmai felkészültséget, problémamegoldó-képességet, önállóságot, gyors döntéshozatalt és alkalmazkodóképességet igényel (Pfau, 1998).

Ezekkel az elvárásokkal ellentétben Magyarországon a mezőgazdaságban alkalmazott munkaerő szakképzettsége bizony alacsony, különösen igaz ez más ágazatokkal való összehasonlításban. Dorgai és mtsai (2000) vizsgálatai szerint 1980-ban a mezőgazdaságban dolgozó aktív keresők közel háromnegyedének, vagyis 73,4 százalékának 
csupán általános iskolai végzettsége volt, ami kedvezőtlen korösszetétellel is párosult. 1996-ra ez az arány 42,4 százalékra csökkent, de ez a változás a más ágazatoktól való lemaradást nem szüntette meg (Hamza és mtsai 2001). Az aktív keresőknek több mint 40 százaléka még mindig alacsony végzettségü, míg az országos átlag 21 százalék körüli (Berde, 2003).

A Központi Statisztikai Hivatal 2015-ben kiadott tanulmánya szerint 2010. évi általános mezőgazdasági összeírás (ÁMÖ) idején regisztrált 9,2 ezer agrárgazdasági szervezet irányítójának 73\%-a, 6,7 ezer fő rendelkezett valamilyen mezőgazdasági végzettséggel. Az irányítók legnagyobb része, 44\%-a felsőfokú, 22\%-a középfokú, 7\%-a pedig alapfokú mezőgazdasági képzettséggel vezette a gazdaságot, míg 21\%-uk gyakorlati tapasztalattal, 6\%-uk pedig szakmai képesítés és gyakorlati tapasztalat nélkül. Az egyéni gazdaságokban a gazdálkodók és segítő családtagok mezőgazdasági iskolázottsági szintje jóval alacsonyabb, mint a gazdasági szervezetek irányítóié. Esetükben átlagosan 10\% körül alakult a szakmai képesítéssel rendelkezők aránya, amely összességében mintegy 110 ezer főt jelentett. A gazdálkodók és segítő családtagok jelentős többsége mezőgazdasági képzettség nélkül, gyakorlati tapasztalat alapján (76\%) vagy annak hiányában (14\%) gazdálkodott. A mezőgazdasági végzettségü gazdálkodók és segítő családtagok 20\%-a felsö-, 44\%-a közép-, 36\%-a pedig alapfokú szakmai képesítéssel rendelkezett.

A mezőgazdaságban alkalmazott munkaerő alacsony iskolázottsága és kvalifikációs értéke mellett a másik lényeges probléma az életkor kérdése. Hamza és mtsai (2001) által végzett felmérések alapján kapott eredmények egybeesnek a nemzetközi tendenciákkal, azaz az agrárágazatban a foglalkoztatottak életkor szerinti összetétele egyre kedvezőtlenebb. A mezőgazdaságban dolgozók derékhadát 61 százalékos részesedéssel a középkorú és az idősödő korosztályok alkotják, amely az ipar és a nemzetgazdaság egyéb ágazata között is a legmagasabb. Az ágazat alacsony eltartó és jövedelemtermelő képessége nem túlzottan vonzó a fiatalok körében (Berde, 2003).

2005-óta a mezőgazdasági ágazatokban tapasztalható „öregedési” tendencia további felerősödése figyelhető meg a KSH 2013. évi adatai alapján. A gazdálkodók 31\%a 65 év feletti volt 2013-ban, a 35 év alattiak aránya közel 1 százalékponttal csökkent (6,1\%), az 55 év felettieké viszont több mint 2 százalékponttal emelkedett (60\%). Emellett mérséklődött a középkorú gazdálkodók aránya is. A segítő családtagok korszerkezete valamelyest kiegyensúlyozottabb volt. Az 55 év felettiek aránya 2010-ben és 2013ban is $37 \%$, a 35 év alattiak aránya azonban a korábbi 24 -ről $28 \%$-ra emelkedett.

A mezőgazdasági folyamatok egyik legfontosabb jellegzetessége a munkafeladatok egyenetlensége. Ez az idényszerüség már önmagában is komoly foglalkoztatási, szervezési és szervezeti problémákat vet fel. Azt értjük alatta, hogy egy adott időintervallumon belül az elvégzendő feladatok, a munkaterhelések egyenetlenül jelentkeznek. Az idényszerüség, vagy másképp szezonalításnak is nevezhetjük, a mezőgazdasági folyamatok biológiai és időjárási meghatározottságának természetes velejárója. Az, hogy az év különböző szakaszaiban több, más időszakban, pedig kevesebb a munkafeladat, azt jelenti, hogy a mezőgazdasági szervezeteknek az év egy részében több, míg máskor kevesebb munkaerőre van szüksége a feladatok elvégzéséhez. Ez munkaerő biztosítási és szervezeti kérdéseket vet fel. A betakarítási időszakok munkafeladatai csak az adott alkalomra felvett ,idénymunkásokkal” oldható meg. Ilyen problémákkal a legtöbb mezőgazdasági szervezet szembesül. Ezek az idénymunkák sokféle feladatot jelentenek a fizikai jellegü kézimunkától a szállítási feladatokon keresztül a különböző gépi munkákig. Az idényjellegü fizikai, kézi munkafeladatok elvégzésére kvalifikált, szakképzett 
munkaerőt biztosítani szinte lehetetlen. A nyugdíjasok és háztartásbeli nők alkalmazása javíthatna a helyzeten, csak az a probléma, hogy ezeknek a munkáknak túl rövid a biológiai és a technológiai optimuma, azaz nagyobb létszámú munkaerő rövid idejü alkalmazására van szükség.

Az idényszerüség nemcsak munkaerő biztosítási és minőségi kérdéseket vet fel, hanem szervezetieket is. A megjelenő, nagyobb alkalmi munkaerő létszámot, ami jelentős is lehet, valamilyen módon integrálni kell a meglévő szervezetbe. A rugalmasan bővülő, majd csökkenő szervezet mezőgazdasági sajátosság, ami más ágazatokra nem jellemző, illetve nem ennyire általánosan alkalmazott.

A mezőgazdasági munkafolyamatok idényszerüségének, a feladat terhelések állandó változásának és egyenetlenségének a következménye a folyamatos foglalkoztatás nehézsége. A munkaerő egy része csak alkalmi munkavállalóként, idényszerüen foglalkoztatható. Ez eredményezi az országos átlagnál magasabb mértékü fluktuációt. Tóth (2000) felmérése alapján a mezőgazdasági foglalkoztatottak számának jelentős csökkenése - becslése szerint a csökkenés 1990-1998 között 50 százalékos - ellenére a megmaradt létszám folyamatos foglalkoztatását csak a szövetkezetek 58,7 százaléka tudta megoldani.

A kilencvenes években bekövetkező gazdasági változások igen kedvezőtlenül hatottak a foglalkoztatás mértékére, amely a mezőgazdaságra is rányomta bélyegét. Hazánkban a mezö-és erdőgazdaság foglalkoztatási részesedése az 1990. évi 17,5\%-ról 2002-re 6,2 \%-ra mérséklődött, amely 2008-ra további 4,4\%-ra csökkent, majd lassú növekedés volt megfigyelhető. 2010 óta közel 50 ezerrel nőtt az agráriumban dolgozók száma, annak ellenére, hogy a gépesítettség is jelentősen javult. Az elmúlt években ez az arány jelentős mértékben nem is változott.

A többi foglalkoztatási gondokkal küzdő gazdaság a munkanélküli segély időleges igénybevételét ajánlotta dolgozóinak, vagy pedig munkaerő gazdálkodását határozott időre szóló szerződésekkel ésszerüsítette. Kisebb, de korántsem elhanyagolható mértékben az alkalmi munkavállalás lehetőségével igyekeztek enyhíteni a foglalkoztatási gondokon, de a megoldások között előfordult a részmunkaidős foglalkoztatás, az előnyugdíjazás és a nyugdíjas foglalkoztatás is. Az utóbbi formák az adminisztratív teendők és az anyagi terhek miatt nem népszerüek a munkaadók körében, de az alacsony kereseti lehetőségek nem oldják meg a munkavállalók gondját sem. A foglalkoztatási gondokkal párhuzamosan, vagy esetleg annak következményeként a mezőgazdasági szervezetek munkaerő gazdálkodásának egyik kellemetlen jellemzője a magas munkaerőmozgás, fluktuáció (Berde, 2003).

\section{Hogyan lehet a hatékonyságot és a foglalkoztatást a sertéstenyésztésben növelni?}

A technológiai elmaradás egy része pótolható az élőmunkaerő nagyobb arányával, ha az megfelelő gondossággal és lelkiismeretességgel rendelkezik. A feladatra alkalmas embereket sajnos azonban egyre nehezebb találni, ha a klasszikus értelemben vett vidéki életforma egzisztenciális lehetőségei, és társadalmi tisztelete a jelenleg tapasztalható irányba halad.

Napjainkban nem csak a városokban, hanem egyre több faluban is csak potenciális szennyező forrásnak tekintik az állattenyésztést. A lakott területekröl egyszerübb a tevékenységet kitiltani, mint a közösség számára elfogadható körülmények kialakítására 
bírni a gazdálkodókat. Ez hozzáállás sajnos a természettől egyre távolabb kerülő emberiségben azt az érzetet kelti, hogy az állatokkal való munka koszos és undort keltő bárhogyan végzik is.

Az élőmunkaerő foglalkoztatására, és az utánpótlás biztosítására szükséges van a társadalmilag elfogadott és a vidéki közösségekbe beágyazott családi gazdaságokra. Itt a kisebb méretek miatt kisebb a tőkeigény, és kevés személy odafigyelése is működtetni tudja a vállalkozást. A családi gazdaságok azonban csak a nagyobb termelői csoportosulások által, integráltan juthatnak a nemzetközi versenyképesség eléréséhez szükséges feltételek megvalósításához. Az integrációk hatékony müködéséhez viszont a modern nagyüzemek szükségesek. Ezek az üzemek a technológiák kezelését és a technológiai fegyelmet szigorúan betartó, komplex, rendszerszemléletű szakembereket igényelnek, akiket nehéz úgy kiképezni, hogy 18-20 éves korukban találkoznak elöször állatokkal, abban ugyanis minden gazdálkodási nézet közös, hogy a középpontjában az állat igényeinek kell lenni. A kétféle gazdálkodás tehát a humánerőforrás szempontja alapján is kiegészíti egymást.

A gazdaságok tőkehiányos állapota, és az ágazat rövid-távú, nagy szélső értékekkel bíró ciklusossága miatt a technológiai fejlesztések elmaradtak vagy sok esetben csődöt okoztak. A hozzáértő munkaerő fellelhetősége egyre nagyobb nehézségekbe ütközik, így a fejlesztésekre és az ágazati integrációk megvalósítására nagy szükség lenne. Magyarország számára jelenleg rövidtávon előnyt jelenthet a munkabérek alacsonyabb színvonala, ugyanakkor a tartástechnológiai hiányosságok és a komoly ágazati integráció hiánya miatt jelentkező nagy élőmunkaerő igény, összességében általában költségnövelő tényező. Nem elhanyagolható, hogy a magasabb munkaerö létszám és az alacsonyabb bérszínvonal miatt a telepek járványvédelmi kockázata lényegesen nagyobb, mint ott, ahol a dolgozók munkaidő után nem nevelnek disznókat otthon.

Az ország rossz vagyonbiztonsági körülményei az állattartó telepeken hatványozottan vannak jelen. A kisebb lopások (10-20 malac) teljességgel felderíthetetlenek. Nagyságrendjük a felderítés hatékonyságával, az általános erkölcsi színvonallal, az esetleges tettenérések alkalmával foganatosított azonnali, akár fizikai intézkedések hiányával van összefüggésben. A nagy dolgozói létszám, a munkahelyek és a vagyoni javak tiszteletének hiánya nem kedvez az aggasztó helyzet konszolidálódásának! A vagyonvédelemre fordítandó kiadások így messze meghaladják a versenytársak hasonló jellegü kiadásait. Nálunk ez 3-10 Ft/kg, Nyugat-Európában gyakorlatilag nulla.

A magyar mezőgazdaság negyedszázada a válság súlyos problémáival küszködik. Az 1980-as évek végére a nagyüzemi mezőgazdaság belső erőforrás-tartalékai kimerültek, piacai szétestek. Az 1990-es években megvalósított privatizáció pedig egy torz, egyre kevésbé hatékony tulajdonosi és birtokszerkezetet hozott létre, amely növekvő társadalmi problémákat generál. Lecsökkent az ágazat termékkibocsátása, az alapanyagtermelésre épülő élelmiszer-vertikum pedig számos termékpályán lényegében megszünt. A külföldi tőke élelmiszeriparba történő beáramlását ugyanis sok esetben a gyárak megszünése, ezzel a nyugati konkurens élelmiszer-feldolgozók piacszerzése, ezen keresztül pedig extraprofit-realizálás követte. Egyidejűleg a hazai alapanyag-termelés megszünése is bekövetkezett a bezárt feldolgozók körzetében. A magyarországi élelmiszer-vertikum újjászervezésével a vidéki társadalom megerősítése, munkához juttatása, a növekvő élelmiszerimport mérséklésével pedig az ország élelmiszer-biztonsága megteremthető lenne, de sajnálatos módon ilyen irányú törekvésekre kevés példát láthatunk. 
A piaci és a közgazdasági körülmények, a rendszerváltás következményeként gyorsan megváltoztak. A korábbi évekre jellemző termelési és értékesítési struktúrák meghatározó része felbomlott, helyét az egyre erősödő magánszféra foglalta el, a tulajdonosváltásokkal felbomlottak az integrációs kapcsolatok, beáramlott a nemzetközi töke. Ezen tényezők következtében egyre többen hagytak fel sertéstartással, a gazdák csökkentették az állománylétszámukat és sokan felhagytak a termeléssel (Csordás - Kömüves, 2005). A termelés felhagyásának és a szerkezeti átalakulásnak köszönhetően elértük, hogy Magyarországon 2016.-ra már kevesebb, mint 3 millió (2,9 millió) sertést tartanak az országban (2002-ben még több mint 5 millió sertés volt Magyarországon), ami a hazai húsipar szükségleteit már nem fedezi, így Magyarország sertéshúsból importra szorul. Továbbra is a vertikumot érintő általános problémák között szerepelnek a genetikai alapok hiánya, a nem megfelelő naturális mutatók, továbbá a jelentős élőmunka ráfordítási költségek melletti termelés, amelyet elavult és korszerütlen technológiai háttér mellett igyekszünk kivitelezni. Az állattartás szigorú szabályozása, környezetvédelmi elöírások megnehezítik elsősorban a földterülettel nem rendelkező gazdaságok müködését, mely korlátok átreformálása, átgondolása könnyítést jelentene a még müködő telepek számára.

A nem megfelelően képzett- sokszor hozzá nem értő- dolgozók, a kirakatszervezetként müködő érdekképviseletek, illetve a feldolgozóiparral való együttmüködés hiánya is érzékenyen érinti az ágazatot.

A magyar mezőgazdaság világszintü elismerésének, és megbecsülésének - ezek a magyar köztudatban is hiányoznak - visszaállítása, a magyar élelmiszerellátási- lánc rekonstrukciójának megvalósítása sürgős feladata lenne az erre jogilag és politikailag felhatalmazott szerveknek. Ebbe beletartozik az oktatás reformjától, a termőföld tulajdonviszonyainak rendezésén keresztül, a termelötevékenységet folytatók megfelelő támogatáspolitikáján át, feldolgozó-iparban lévő feszültségek feloldása is, mellyel nemcsak munkahelyek teremtése, hanem egy bizonyos fokú" gazdasági jólét", és társadalmi megbecsülés is megvalósulhatna.

\section{Kutatások és eredmények}

A Közszolgálati Humán Tükör 2013-ban készített tanulmánya részletesen foglalkozik a HR modellezési lehetőségeivel, egyes területek mérési módszereivel, a magán- és közszférában betöltött szerepével, jelentőségével. Kutatásukban vizsgálták kérdőívek eredményeinek feldolgozása alapján a HR terület által ellátott fö humánfolyamatok és azok funkciói hogyan és milyen formában, milyen megítélés mellett müködnek.

1. A HR tevékenység meglétére vonatkozó eredményeket az 1. ábra mutatja. 
1. ábra. A HR tevékenység megléte

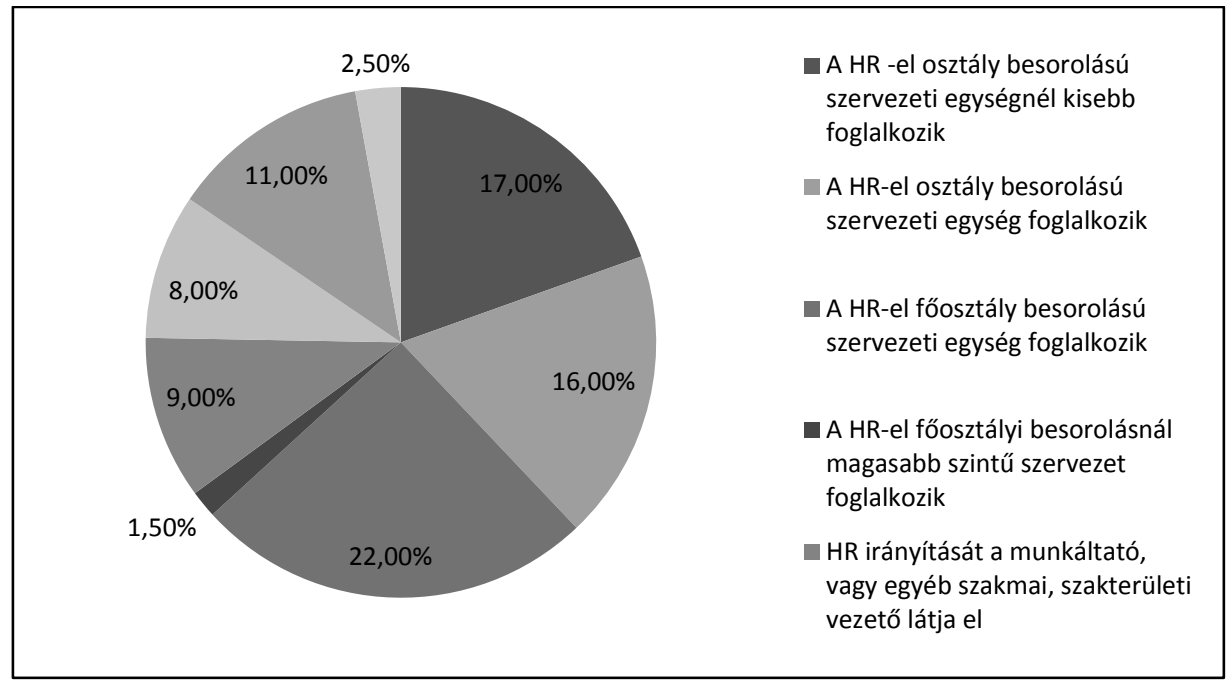

Forrás: Petró 2013

A szervezetek megközelítőleg 15\%-nál nincs külön csak az emberi erőforrás gazdálkodással foglalkozó szervezeti egység, meglepö, hogy van olyan szféra ahol nincs külön HR munkatárs sem. A tanulmány részletes eredményei között szerepel a HR jelentősége az államigazgatási szektorban. Az államigazgatásban a legjellemzőbb, hogy az emberi erőforrás gazdálkodással főosztály besorolású szervezeti egység foglalkozik.

2. A HR terület szervezeten belüli elhelyezkedése

2. ábra. A HR terület szervezeten belüli elhelyezkedése

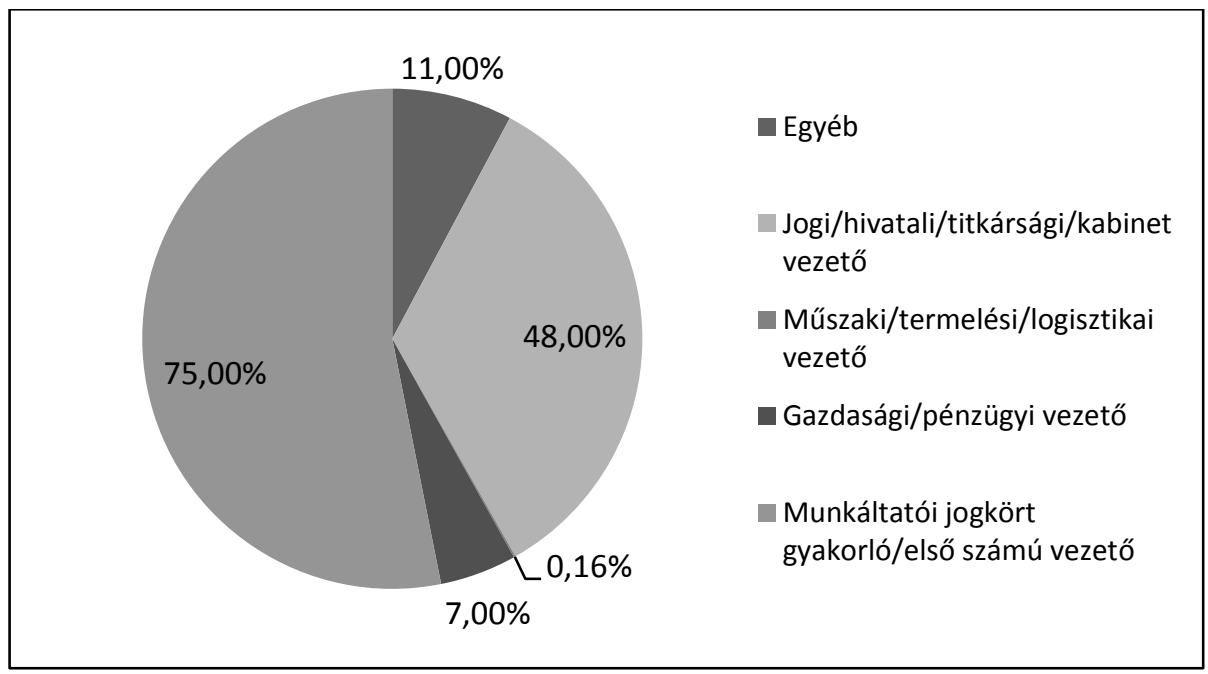

Forrás: Petró 2013 
Arra a kérdésre, hogy „ha van az emberi erőforrás gazdálkodással foglalkozó szervezeti egységnek önálló vezetője, akkor kinek az irányítása alá tartozik?” a válaszadók nagyobb hányada szerint a HR részleg a munkáltató jogkört gyakorló, vagy az első számú vezető irányítása alá tartozik. A válaszadók véleménye szerint 48\%-ban tartozik jogi, hivatali, titkársági vagy kabinetvezető munkaköri feladatai közé. A többi pedig elenyésző számban jelenik meg, amely szerint a HR és a felső vezető közé ritka esetben ékelődik be egy nem HR területi vezető, aki az irányítása alatt tartaná a területet. Ez utóbbi döntően a kisebb szervezeteknél, munkaszervezési okokból fordul elö. Ha a HR feladatokkal csak 1-2 fő foglalkozik, akkor sokszor előfordul, hogy közvetlenül az első számú vezető irányítása alá tartoznak.

\section{A HR terület szervezeten belül betöltött szerepe}

A kérdőívben arra keresték a választ, hogy a válaszadóknak mi a véleménye, a HR jelenleg milyen pozíciót tölt be a szervezetben? Ennek keretében a válaszadóknak feltett kérdés:

„Az emberi erőforrás gazdálkodással foglalkozó szervezeti egység(ek)nek vagy szakember(ek)nek jellemzöen milyen kapcsolata van a felsővezetéssel?"

3. ábra. A HR terület szervezeten belül betöltött szerepe

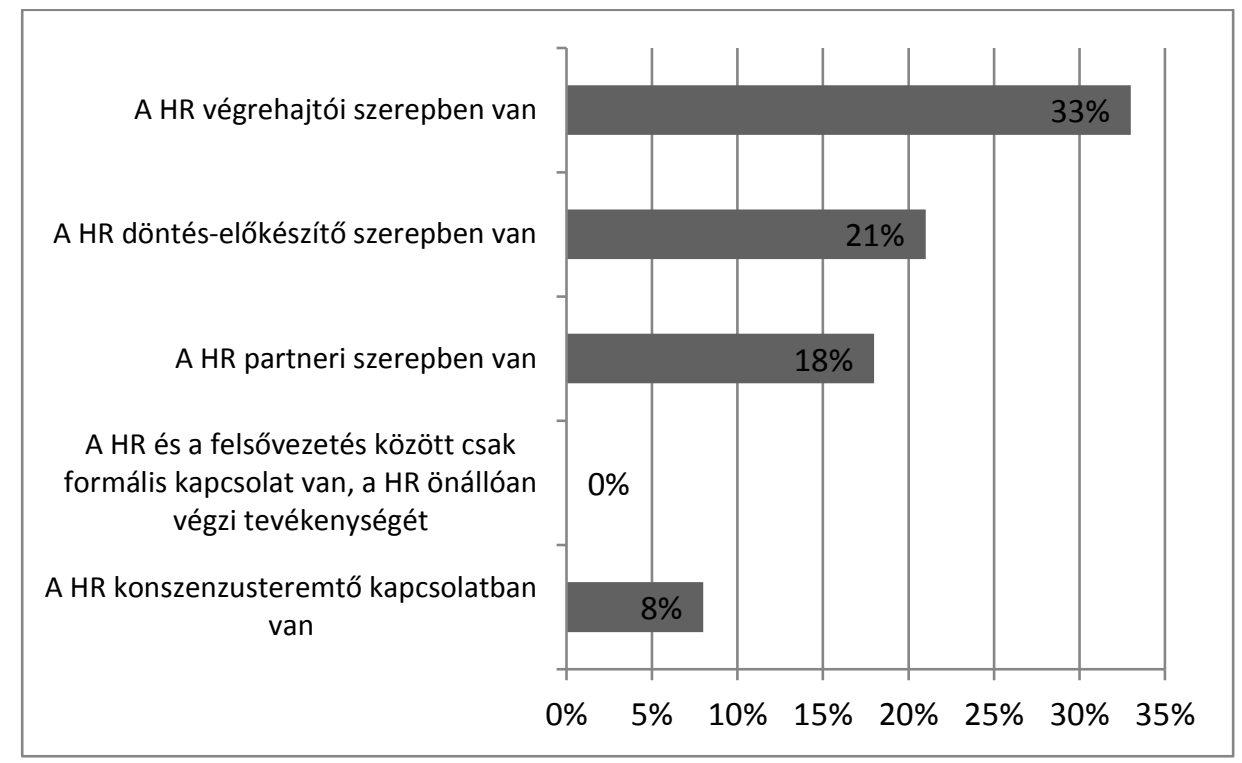

Forrás: Petró 2013

Az eredményekből láthatóan a válaszadók vélelmezzük, hogy óvatosan fogalmaztak, vagy nem tudták megítélni/félreértették a kérdést, mert a kérdéscsoportra az ötfokozatú skálán adott válaszok esetében a középértékek aránya a legmagasabb, vagyis a kérdésekre főként a „csak részben jellemző” válaszok érkeztek túlsúlyban, átlagban 30$35 \%$ körüli értékben, amely inkább a bizonytalanságból eredő „,is-is” válaszokat generálhatott. Azért, hogy egyértelmű képet kapjunk a válaszadói preferenciákról, a három 
szféra legmagasabb, „teljes mértékben jellemző” kategóriába eső válaszait átlagoltuk. Ez alapján látható, hogy a válaszadók 33\%-a szerint a HR végrehajtó szerepben van, $21 \%$ szerint része a döntés-elökészités folyamatának.

Egy válaszadó sem tartotta formális jellegünek a felső vezetés és a HR kapcsolatát, amely arra enged következtetni, hogy a HR teljes mértékben a felső vezetés irányítása alatt végzi munkáját. A HR partneri szerepe a válaszadók $18 \%$-a szerint jellemző. A HR terület szofisztikáltabb, konszenzusteremtő szerepe csak 7\% szerint jellemző, amely várakozásainknak megfelelö értéket mutat.

Nem mellékes milyen módon szereznek munkájukkal kapcsolatos információt az egyes cégek HR vezetői. Egy 2014-es kutatás szerint a HR szakemberek tájékozódásainak, mintegy szakmai fejlődésének forrását leginkább online vagy személyes megjelenést igénylő fórumokon szerzik, ez a megkérdezettek 17\%-át tette ki. A képzésekettréningeket $20 \%$-ban tekintették előnyben, a konferenciák 17\%-ban, online platformok és online folyóiratok 15-17\% ban a legnépszerübbek között említhetők; ezek összességében majdnem 70\%át adják az elsődleges tájékozódási forrásoknak. Az írott forma kevésbé népszerü; a szakkönyvek, folyóiratok csak 7-8\%-ot tesznek ki. Személyesen legszívesebben más kollégáktól kérdeznek, majd szervezeti tanácsadótól, de tudományos kutatót szinte senki nem említett (Uatkán, 2014).

Berde 2003-ban végzett és azóta meg nem cáfolt eredményei azt mutatják, hogy a mezőgazdasági vállalatok vezetői a legfontosabb feladatnak a teljesítményértékelést és ösztönzést tartják, míg legkevésbé fontosnak az emberi erőforrások fejlesztését ítélik meg. Hasonlóan kisebb jelentőségünek minősítik a személyzeti információs rendszert és a munkakör kialakítást, értékelést. Az emberi erőforrás fejlesztésének ilyen mértékü leértékelődésében az jut kifejezésre, hogy a mezőgazdaság jövedelemtermelő-képessége az elmúlt években nem tette lehetővé, hogy a mezőgazdasági szervezetek képzéseket szervezzenek és támogassanak.

Az emberi erőforrás feladatainak megítélését számos tényező befolyásolhatja, így a szervezet mérete, profilja, tevékenysége, a vezető személyisége, de maga a vezetési szint is. Az EEM feladatainak vizsgálatát kiterjesztették a szerint is, hogy a vezető milyen helyet foglal el a szervezeti hierarchiában.

1. táblázat. Az EEM feladatainak vezetői szintenkénti rangsorolása

\begin{tabular}{|c|c|c|c|c|}
\hline \multirow[b]{2}{*}{ Feladatok megnevezése } & \multicolumn{3}{|c|}{ A feladatok rangsora } & \multirow{2}{*}{$\begin{array}{l}\text { Átlagos } \\
\text { rangsor }\end{array}$} \\
\hline & Felsőszint & $\begin{array}{c}\text { Középső } \\
\text { szint }\end{array}$ & Alsószint & \\
\hline 1. Munkaerő-tervezés & 5 & 3 & 1 & 2 \\
\hline 2. Munkaerő-ellátás & 2 & 5 & 4 & 4 \\
\hline 3. Munkakör-kialakítás, értékelés & 8 & 7 & 5 & 5 \\
\hline 4. Ösztönzésmenedzsment & 1 & 4 & 2 & 1 \\
\hline 5. Teljesítményértékelés & 3 & 1 & 3 & 3 \\
\hline 6. Az emberi erőforrások fejlesztése & 4 & 6 & 8 & 8 \\
\hline 7. Egészség- és munkavédelem & 6 & 2 & 6 & 6 \\
\hline 8. Személyzeti információs rendszer & 7 & 8 & 7 & 7 \\
\hline
\end{tabular}

Forrás: Berde 2003 
A teljesítményértékelési vizsgálat eredményei is arra utalnak, hogy a megkérdezett vezetők elsősorban a munkateljesítményeket jól kifejező munkanormákat, és a múltbeli teljesítményeket minősítik fontosabbnak, és még a jövőben is ennek a két módszernek tulajdonítanak nagyobb jelentőséget.

4. ábra. A teljesítményértékelési módszerek vezetői értékelése

Jelenben

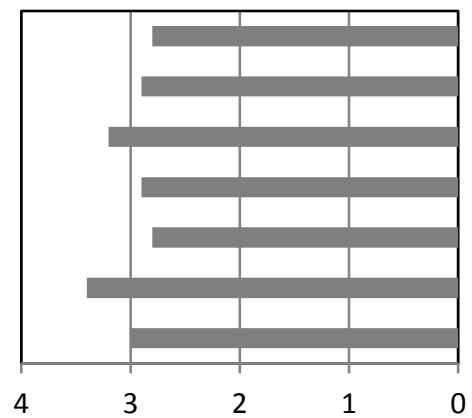

Jövőben

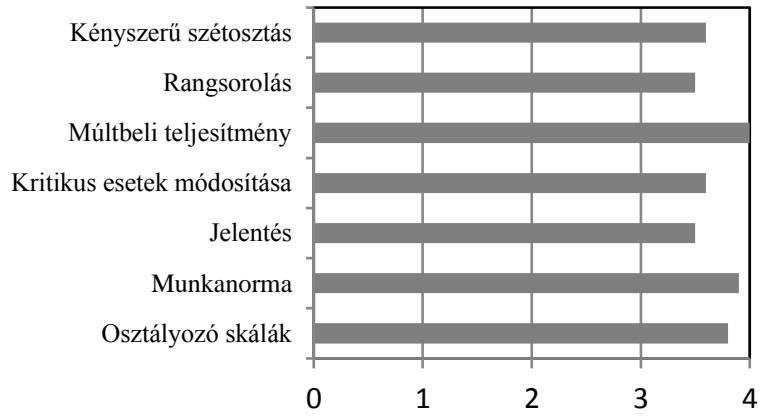

Forrás: Berde 2003

Az 1. táblázat adataiból az EEM feladataira vonatkozóan az alábbi megállapítások tehetök:

- A munkaerő-tervezésnek az alsószintü vezetők tulajdonítanak a legnagyobb jelentőséget, a másik két szint ezt nem minősíti döntő fontosságúnak.

- A munkaerő-ellátást a felsőszintű vezetők tartják fontosnak.

- A munkakör-kialakítás, értékelés mind a három vezetői minősítés szerint az egyik legkevésbé fontos feladat.

- Az ösztönzésmenedzsment fontosságát mind az alsó- és felsőszintű vezetők kiemelték, a középszintű vezetők viszont nem tartják meghatározónak.

- A teljesítményértékelést a középvezetők rangsorolták az első helyre, de a két másik vezetési szint szerint is a rangsor első felében található.

- Az emberi erőforrás fejlesztés feladatainak rangsorolása azt mutatja, hogy sem a középvezetők, sem az alsószintü vezetők nem tulajdonítanak neki nagy jelentőséget. Az alsószintü vezetőknél ez a rangsorban az utolsó.

- Az egészség- és munkavédelem a középvezetők véleménye szerint fontos vezetői feladat, míg a két másik vezetési szintnél a rangsor utolsó harmadában található.

- A személyzeti információs rendszer fontosságát jelenleg még egyik vezetési szint sem ismeri el.

Az utóbbi évtizedben, a mezőgazdasági ágazatban, a tulajdonviszonyokban, a szervezeti keretekben, a müködési formákban, a termelési szerkezetben, a piaci viszonyokban bekövetkezett változások, a munkaerővel kapcsolatos elvárásokra is hatottak. A vezetői interjúk készítése során arra is választ kerestek, hogy a mai mezőgazdasági szervezetek vezetői milyen elvárásokat fogalmaznak meg az alkalmazottaikkal szemben és ezen elvárásokat, hogyan minősítik.

A kutatók a vizsgálataikat a következő tényezőkre fókuszálták: szakképzettség, gyakorlati tapasztalatok, feladatoknak való megfelelés, munkakörnek való megfelelés, 
rugalmasság, rátermettség, kreativitás, állóképesség, alkalmazkodóképesség, együttmüködő képesség. Az eredmények a 5. ábrán láthatóak.

5. ábra. A munkaerővel kapcsolatos elvárások vezetői minősítése

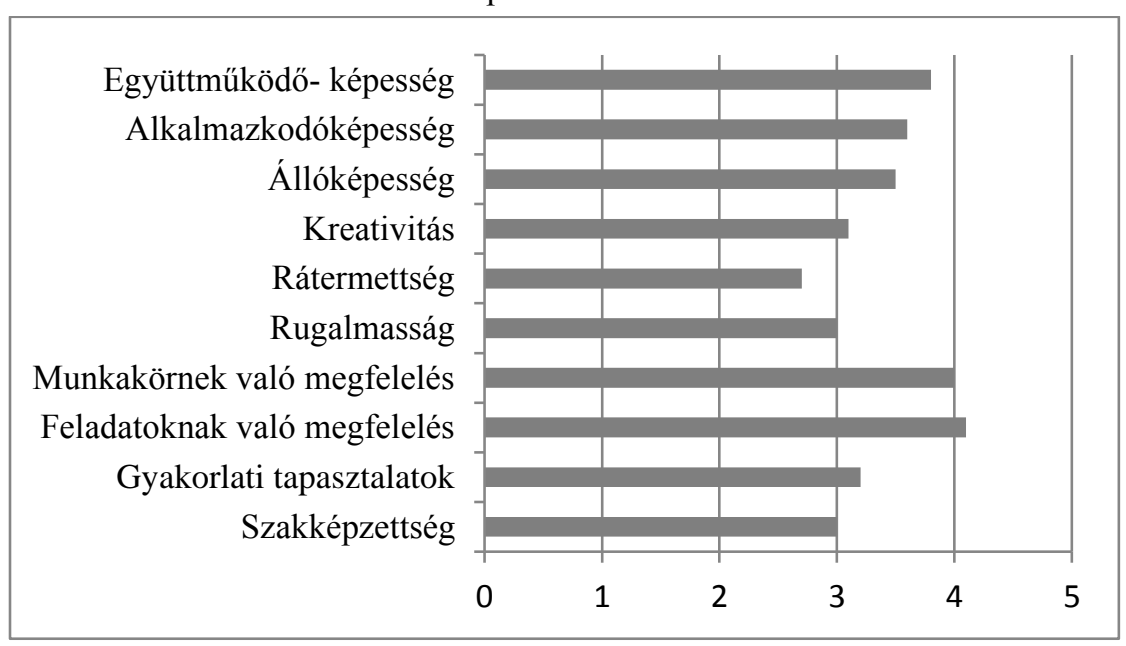

Forrás: Berde 2003

A vezetői véleményekben a legfontosabb elvárás, a feladatnak, illetve a munkakörnek való megfelelés, valamint az együttmüködési készség. Meglepő, hogy a szakképzettség nem szerepel a legfontosabb vezetői elvárások között. Az eredményeket a kutatás során további részegységekre bontották, felső-, közép és alsó vezetői szintenként is. A vizsgálat arra irányult, hogy a vizsgált elvárások minősítésében van-e különbség a különböző szinteken dolgozó vezetők véleményében (6. ábra).

6. ábra. A munkaerővel kapcsolatos elvárások vezetői szintenkénti értékelése

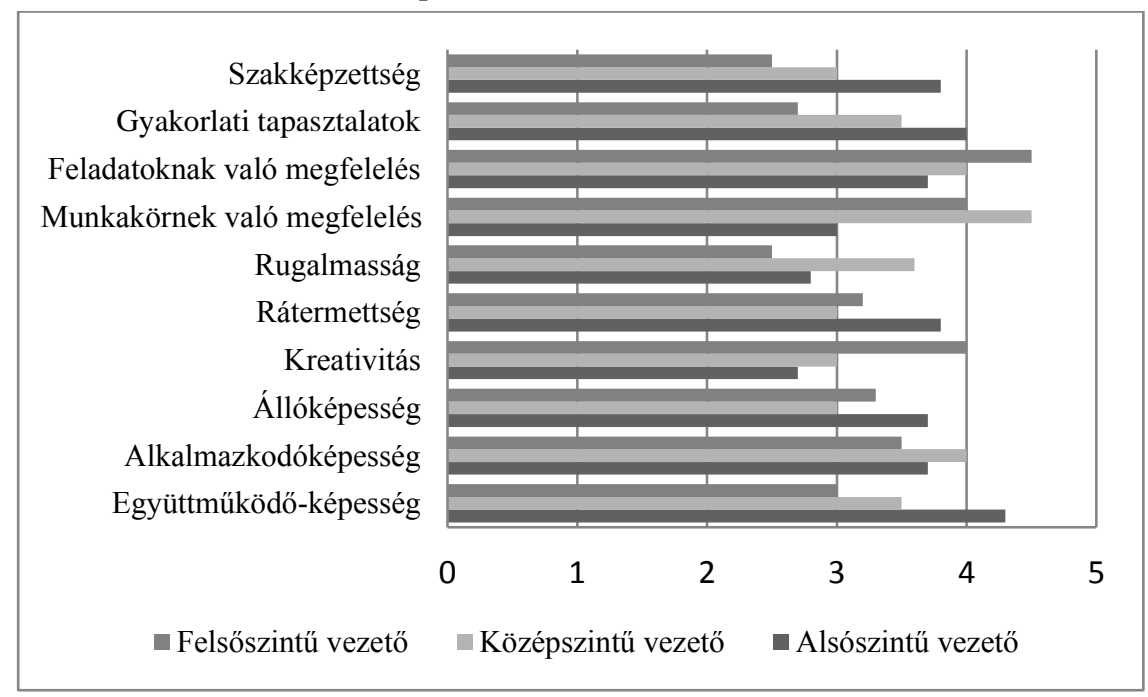

Forrás: Berde 2003 
Elvárásaik között a legkevésbé fontosnak a szakképzettséget és a rugalmasságot tartják. A középszintü vezetők elvárásai közül a munkakörnek és a feladatnak való megfelelés emelkedik ki. Az eredmények alapján összességében megállapíthatjuk, hogy a mezőgazdasági szervezetek vezetőinek a dolgozókkal szembeni elvárásaiban, a szakképzettség jelentősége mintha leértékelődött volna, a feladatnak és a munkakörnek való megfeleléssel szemben.

Az elvárásokat a vezetők adott szervezeten belüli státusza, a hierarchiában elfoglalt helye jelentős mértékben befolyásolja (Berde 2003).

\section{Összefoglalás}

A hazai mezőgazdasági szektor szereplői a megváltozott gazdasági környezetben igyekeznek megfelelni a külföldi piaci élet elvárásaihoz. Az igazi kihívás a naturális mutatókon és egyéb, a termelést meghatározó gazdasági tényezőkön túl a humán erőforrás területeket érintő változások jelentik. Amennyiben erre nem kerül sor, a nagyobb gazdasági mutatók elérésében csak kevés hazai cég lesz képes megfelelő eredményt megvalósítani. A szervezetek versenyképességét nagyban befolyásolja a humán tőke, és ez által a humánerőforrás gazdálkodás, menedzsment vállalton belül betöltött szerepe, eredményessége. A vezetők számára is kihívást jelent a megváltozott környezethez való alkalmazkodás mértéke, megfelelő vezetési magatartás alkalmazása a siker érdekében.

Napjainkban a humán erőforrás menedzsment, mint tudományterület folyamatos fejlődése tapasztalható, mind elméleti, mind módszertani megközelítésből. Az alkalmazásával viszont, különösen a volt keleti blokk országaiban, komoly gondok adódtak. Egyrészt hiányzik a felsőfokú vezetők képzési rendszeréből ez a szakterület, másrészt e területen dolgozók szemléletétében jelentős változtatásokra lenne szükség, mely szerint nemcsak menedzseri érdekeket hivatottak szolgálni. A korlátozó tényezők együttes hátasainak, és a mezőgazdasági ágazatokat sújtó gazdasági környezet negatív változásának köszönhetően romlott a munkahelyi légkör, csökkent az emberek elköteleződése, nőtt az elégedetlenségük. Az egyes mezőgazdasági ágazatokban megfelelően alkalmazott humánerőforrás gazdálkodás eredményeképpen erősödhetnek az alkalmazottak attitüdjei, nőhet az innovativitás, mely a versenyképesség megőrzésének, növelésének egyik meghatározó tényezőjévé vált. 


\section{Felhasznált irodalom}

Berde Csaba (2003): Az emberi erőforrás gazdálkodás vezetési kérdései a mezőgazdaságban. Agrártudományi Közlemények - Acta Agraria Debreceniensis 2003/12, 1-9., http://www.date.hu/acta-agraria/2003-12/berde.pdf.

Dr. Bittner Péter (2011): A humán erőforrás menedzsment kihívásai a XXI. században https://kgk.sze.hu/images/dokumentumok/kautzkiadvany2011/emberi\%20eroforrasok/BittnerP.pdf

Buzás Gy. (2001): A gabonatermesztés szervezése és ökonómiája. In Pfau E. - Széles Gy. (szerk.): Mezőgazdasági Üzemtan II. Budapest, Mezőgazdasági Szaktudás Kiadó.

Chikán A. (1999): Vállalatgazdaságtan. Budapest, Aula Kiadó.

Csordás E.- Kömüves Zs.: A magyar sertés ágazat elmúlt 15 éve a számok tükrében, XI. Ifjúsági Tudományos Forum, Keszthely, 2005. március 24

Dobák M. (1999): Szervezeti formák és vezetés. Közgazdasági és Jogi Kiadó, Budapest.

Dorgai L. - Hamza E. - Misk K. - Székely E. - Tóth E. (2000): Az agrárágazat foglalkoztatásának helyzete, az 1990-1998 közötti változások jellemzői. Agrárgazdasági Tanulmányok 13. Budapest.

A sertéságazat helyzete és a kibontakozás lehetséges irányai Magyarországon; (2011) A sertés lobbi. http://www.termelotol.hu/sites/default/files/sertes_agazati_lobbi_ kerdesek.pdf

Fejes L.: (2013): Az emberi erőforrás menedzsment általános kérdései, fejlödése, elméletei. https://anzdoc.com/az-emberi-erforras-menedzsment-altalanos-kerdeseifejldese-e.html

Fekete Rita (2006): A minőségmenedzsment és az emberierőforrás- menedzsment kapcsolata az agrárvállalkozásokban Doktori értekezés, Szent István Egyetem, Gödöllö pp: 26

Hajós László, Berde Csaba (2007): Emberi erőforrás gazdálkodás. Humánerőforrás Fejlesztési Operatív Program Kiadvány.

Hamza E. - Miskó K. - Tóth E. (2001): Az alkalmazkodóképesség és a rugalmas foglalkoztatási formák szerepe az agrárágazatban. Agrárgazdasági Tanulmányok 2. Budapest.

Központi Statisztikai Hivatal 2015: A mezögazdasági képzettségüek társadalmi jellem$z o ̈ i$; www.ksh.hu

Lentner Csaba (2010): A magyar élelmiszervertikum újjászervezésének stratégiai kérdései.https://polgariszemle.hu/archivum/52-2010-aprilis-6-evfolyam-2szam/377-a-magyar-elelmiszer-vertikum-ujjaszervezesenek-strategiai-kerdesei

Lentner Csaba (2016): Rendszerváltás és pénzügypolitika. Tények és tévhitek. Akadémiai Kiadó, Budapest.

Lepp Katalin (2008): A teljesítményértékelés kapcsolata a humánerőforrás menedzsment különböző területeivel, http://acta.bibl.u-szeged.hu/34607/1/vikek_014 _015_197-205.pdf

Lévai Z. (1992): A személyügyi szervezetek megjelenési formái. Munkaügyi Szemle.

McKenna, E. - Beech, N. (1998): Emberi erőforrás menedzsment. Panem KFT, Budapest.

Petró Csilla - Stréhli-Klotz Georgina:(2013) Az emberi erőforrás menedzsment terület munkavégzésének jellemzői a közszolgálatban; „Közszolgálati Humán Tükör 2013" résztanulmány 
Pfau E. (1998): A mezőgazdasági vállalkozások termelési tényezöi, erőforrásai. Egyetemi jegyzet. Debrecen, Debreceni Agrárcentrum.

Piros M (2002): A humánerőforrás-fejlesztés lehetőségeinek vizsgálata a mezőgazdaságban. $\mathrm{PhD}$ értekezés, Debrecen.

Széles Gy. (2001): Az állattenyésztő ágazatok szervezése és ökonómiája. In Pfau E. Széles Gy. (szerk.): Mezögazdasági Üzemtan II. Budapest, Mezőgazdasági Szaktudás Kiadó.

Tóth E. (2000): A foglalkoztatási jogviszony és a szociális juttatások módosulása. Agrárgazdasági Tanulmányok 12 . Budapest.

Uatkán Anna (2014): Alkalmazzák-e a szervezetben dolgozó HR-szakemberek a szervezetikutatás eredményeit? Alkalmazott pszichológia 2014,14(3): 91-109

A müre a Creative Commons 4.0 standard licenc alábbi típusa vonatkozik: CC-BY-NC-ND-4.0. 